\title{
バスターミナル計画についての考察
}

(都市再開発計画に関する研究、その 7)

$\begin{array}{ccc}\text { 正会員 伊 } & \text { 藤 } & \text { 滋* } \\ \text { 同 } & \text { 渡 辺 俊 } & \text {-** }\end{array}$

序

街路交通量の一般的な予測とともに、所謂交通施設の 規模とその配置の予測が、再開発計画の一環として要求 される。我々はこの增加する交通量を処理する施設とし てのバスターミナルについて検討を加えてみた。そし て、ここでは我タの考えとそのすすめ方を示してみた。

\section{§1. バスターミナルの概念}

(1) バス交通の将来性

自家用車は自由性、機動性等の長所を有しながらも、 都市交通の本命とはなりえないものである。もしてれに よつて都市交通を支えようとすれば、道路と駐車場への 巨大な投資をよぎなくされる事は明らかである。故に都 市交通の中心は大量輪送機関になければならない。

我々は人口 34 万（1970）の岡山市をバスによる健全 な都市交通をもつ都市にしたいと考える。なぜなら、バ スは鉄道、軌道にくらべて、フレキシブルな路線系統を もちうるし、高価な建設を必要としない。また事実、34 万の都市では鉄道によつて構成する事は不可能である。

第 1 図は岡山県の バスの乗車習慣と県 民所得との関係を示 したものであるが、 非常によい相関性を もつている。

我々はバスを積極 的におしすすめたい のでこの相関関係は 直線でつづくものと 仮定する。

今仮りに、所得倍 増計画により 1970

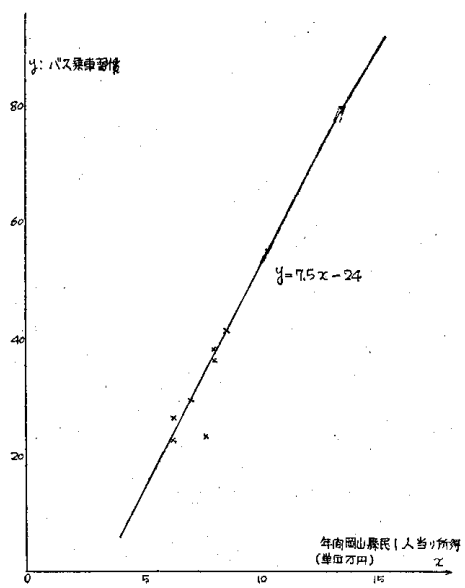

第 1 図 バス乗車習慣と 所得との関俰
年の岡山市民一人当り所得を約 21 万円とすると、この ままでは約 134 のバス乗車習慣となる。これは現在のほ ぼ3倍になつている。

さらに道路の整備とあいまつて長距離の都市間バスが 出現する事を考えると、バス交通の前途は洋々たるもの であると同時に、とれらのための施設を適切に計画して おかないと大きなあやまりをお加す事になるであろう。

(2) バス交通の施設

\footnotetext{
* 東京大学大学院学生
}

バス交通のための基本的な施設は次のようになる。

a) バスガレージ

市街地周辺部に位置して、バスに対する諸サービス （整備、修理、点検）及び格納を行う。バスの起点又は 終点となる。

b) バスストップ

一般方街地街路上にあつてバス乗降のための最も簡単 な施設。原則として通過バス。

c) バス広場

駅前広場、競技場等の如く多量の旅客が乗換えあるい は乗降する場所である。通過バスのための複数のバスス トップであり、原則として運転調整は行わない。

d) バスターミナル

都心部に近く位置し、通勤及び買物交通のための終点 として、郊外人口の都心への放射吸引の中心となる。旅 客に対するサービスに重点がおかれ、案内所、出札室、 一時荷物預り室、食堂、売店などの施設がともなう。現 在各地で、バス夕ーミナルあるいはバスステーションと いわれているものは純䊉な意味でのバス広場とバスター そナルとの未分化の状態のものであると考えられる。

(3) 駅としてのバスターミナル

1960 年現在、国鉄岡山駅の乗降人員は一日約 8 万人 であり、一方中心㧼地にある天满屋バスターミナルは 約 5 万人と推定されている。将来のバス交通の発展を考 え、さらにショッピングとオフィス地区の中心にあると いう利点を考えると、都市において今後国鉄駅と同程度 ないしはそれ以上の吸引力をもつ施設となる事が予想さ れる。

東京や大阪等で私鉄のターミナルにあるデパートが栄 えているように、バス交通とバスター之ナルを適当に計 画するならば、それらより一まわり小さい都市における 立派な核になるであろう。

(4) 天満屋バスターミナルの限界

現在天満屋バスターミナルの敷地面積は約 $3,300 \mathrm{~m}^{2}$ であるが、この処理限界は約 850 台である。現在すでに 終日発着台数が 750 台をこえているので、この分では数 年のうちに面積的限界に達するであろう。

さらに、今のところ中鉄バス、宇野バス等近くにバス ガレージ兼発着所をもつ会社のバスはこのターミナルを 使用していないので、完全なバスターミナルとしての機 
能を持たせるためにはてれらのバスを入れなければなら ないが、現在でもはや天満屋バスターミナルには、これ 等をうけいれる容量はない。

天満屋バスターミナル出入口の表の道路は、巾員 $15 \mathrm{~m}$ で終日交通量約 1 万台 (1960年・含軽自動車)である。 てれが事実上は往復 2 車線にしか使われていないのでも はや道路容量の限界江来ている。さらにての道路はショ ッピングストリートを横断している事を考えあわせて、 このうえ大型のバスによつて混乱を助長する事はさけな ければならない。

\section{§2. バスルートの計画}

(1) バスの種類

バスルートはそれぞれ、市内バス、郊外バス及び都市 間バスについて考察する。

a）市内バスは主に都市内の業務交通に供されるもの で、環状的運行ないしは短距離往復運行をする。人口密 度 150 人/ha 以上の市街地では昼間最大間隔は 5 分と し、バスストップまでの徒歩距離を $500 \mathrm{~m}$ 以内としたい。

b）郊外バスは主に都心への通勤及び買物交通に供さ れるもので、都心対して放射状に集中するバスルート を持つ。市内バスが原則としてバスターシナルへ入らな いのに対して、郊外バスはその起点又は終点をバスター そナルに持つ。

c）都市間バスは現在未だ一般的ではない。1959 年 現在、中国地方では $150 \mathrm{~km}$ 以上の路線をもつ運行系統 は 15 本であり、その運行回数は合計一日 15 本にすぎな い。しかしそのうちには岡山・松江間 $(196 \mathrm{~km})$ の如き 長距離もふくまれているので、将来の道路整備に伴い、 大阪・下関間くらいの都市間長距離バスの出現もそう遠 い事ではないと思われる。その場合には、岡山はそれら の中継地及び発着地になる充分な資格をもつている。

(2) バスターミナル・バス広場システム

岡山市の中心、東西、南北ほぼ $1 \mathrm{~km}$ 四方の市街地をま

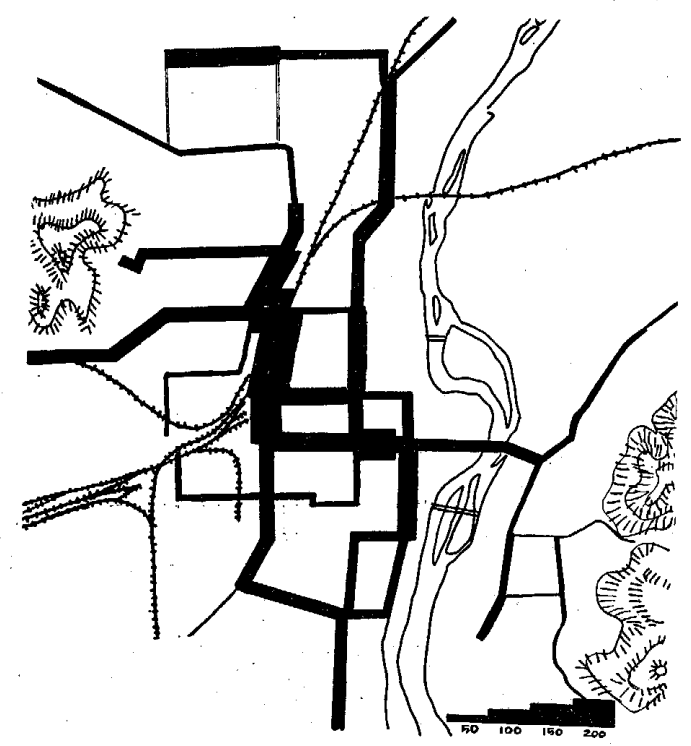

第 2 図市内バス交通帯図
わる道路を中央環状線とする。その北西のすみに国鉄岡 山駅があるので、そてにバス広場をとり、東の一辺のほ ぼ中央にバスターミナルをおく。バス広場とバスターミ ナルの間を中央環状線にそつてむすぶと、1.5 km ない し $2.8 \mathrm{~km}$ になる。市内バスでは時速 $20 \mathrm{~km}$ で運行す るとしてその所要時間任 5 分ないし 9 分となるので、 バス広場では運転調整を行うととなく、どんどん発着す る事にする。郊外バスはこの中央環状線から外部へ放射 状のルートをもつが、決して環状線の内部に入らない様 にする。

てのシステムによれば、駅前の交通のはげしい場所で バスが待留する時閒を短かくし、交通能率を上げる事が できる。また郊外及び都市間バスが都心のターミナルと 駅前とを往復する無䭾な二重交通を防ぐ事ができる。

(3) 路面電車に対する考察

1960年 5 月現在岡山市の路面電車は、営業路線延長約 $5.57 \mathrm{~km} 、 1$ 日乗客数約 32,000 人、営業 1 キ口当り利用 者数は 1 日 5,770 人である。東京の都電は 1956 年以来 7,600 人で頭うちになつているが、電車の定員、路線延 長などを考虑に入れると岡山でも同様に斜陽の傾向にあ るのではないかと思われる。また、中国地方全体の軌道 合計では 1959 年度の対前年比が定期 106\%、定期外 96 $\%$ 、合計 $100 \%$ の成積であり、岡山の路面電車は各々 97 \%、91\%、合計 $93 \%$ となつているのである。

ての路面電車を経営している岡山電気軌道 $\mathrm{KK}$ K 同時 に、市内バスを経営している唯一の会社でもあるので、 将来逐次路面電車をバス化して行くうえで、都合がよい と思われる。路面電車のバス化によつて、道路は一層能 率よくなり都市内部の大量交通は唯一のバスという交通 機関によつて明解に処理される事方河能になる。

(4) 将来の開発の方向

岡山周辺の交通量の增加を調べていくうちに、東西方 向すなわち国道 2 号線の交通量の増加がいちじるしい事 がわかつた。都市内交通がこの増加しつつある通過交通 によつて混乱されないために、我々は将来の市街地の発 展の方向を南北方向に選んだ。そのため、南部の住宅計 画地区からは、鉄道や川に邪魔されるととなく容易に都 心のバスターミナルへ乘り込む事が出来るようになる。

\section{§3. バスターミナルの位置}

(1) ラッシュ率

終日交通量の中である特定の一時間の交通量のしめる 割合をラッシュ率と定義する。通常ての指標には人間の 数をとり、時間は多くの場合、 7 時〜8 時とか 7 時半〜 8 時半とかいうように測定しやすい1時間をとる。

さて都心に対する通勤現象のはげしい所では交通量の ピークができてしまう。これれに対して都市内活動（業務 ・買物・レクリエーション) の比重の大きい所では、比 較的毎時間平均した交通量が発生する。 
施設について考えると、每時間平均して使われる方が 能率がよい事は明らかである。あまりにピークの值が大 きすぎるとその時にあわせて設計された施設は、他の時 間には遊ぶ事になるからである。ピークの交通量がかな り大きい時には、なるべく特定時間帯への集中をさけつ つ、ピークをさばく事ができればもつと能率は上つてく る。以下にラッシュ率と通勤業務との関係を示す。

\section{第 1 表}

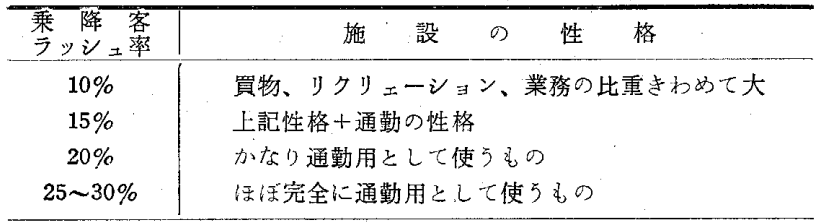

ラッシュ率 $25 \%$ 以上といえぼ東京の中央線快速電車 級であり、健全な施設とはいいがたい。一般にバスター ミナル周辺の性格としてはラッシュ率で 10〜15 ないし 20\%になるものが適正なのではないかと思われる。

(2) 岡山バスターミナルの位置

環状線の東の一辺のほぼ 中央環状線内側に約 $70 \mathrm{~m} \times$ $190 \mathrm{~m}$ の道路と平行の細長い敷地が選ばれた。この西側 は岡山の商業地区であり、東側は業務中心及びシビック センターとなつている。てれらはバスターミナルを中心 にほぼ $500 \mathrm{~m}$ 以内の徒歩圏に位置し、コンパクトな新し い都市のコアとして計画されている。

これらの環境のためにターミナルの乗降客ラッシュ率 は、約 $12 \%$ と推定されている。現在天満屋ターミナルで のバスラッシュ率は 8.8\%（1960年1月）であるから、 ピーク時の乗車密度を考光て、バスラッシュ率は $10 \%$ くらいではないかと推定される。

(3) 右折の問題

バスターミナルへの出入に関して、最も問題となるの 恃右折現象である。いかにプランニングしようとも、バ スターミナルヘ の出入に注これ がつきものであ る。いま仮りに 終日のバス発着 台数を 3,000 台 とするとバスラ \% シ \pm 率 $10 \%$ として、ピーク 時には、一時間 に300台の車が 発着する事にな る。もし出入口 が同じあるいは 分汃ていても ごく近傍の場合

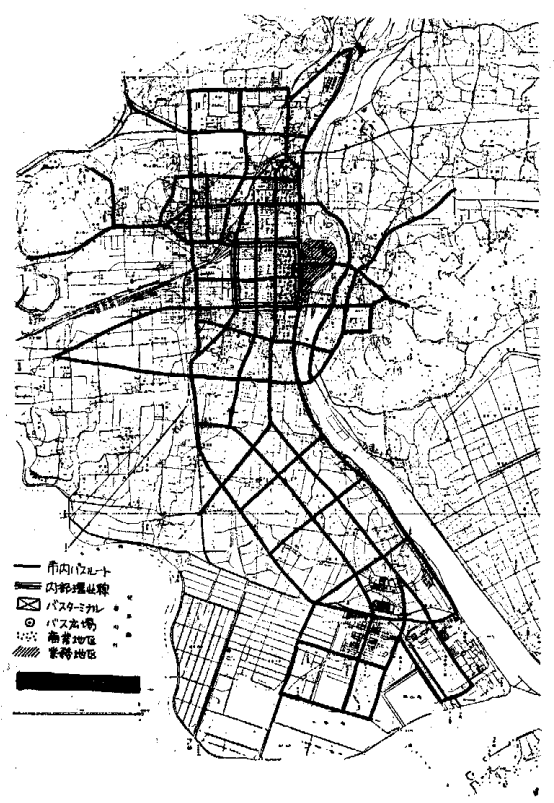

第 3 图 市内パスルート計画図
には発着台数と同数 の右折が行われて、 バスは道路からター ミナルへ出入するの である。一分間に 5 回といえばてれは大 変な交通混乱を引き おこす事になる。

右折学解決するに は次の方法がある。

a) 出入口を地下 道あるいはオーバー ブリッジにするか (例 : ニューヨーク・ ポートオーソリティ

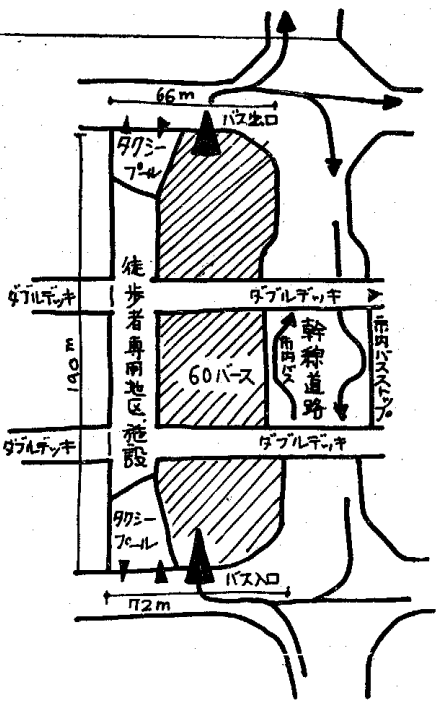

第 4 図 岡山バスターミナル説明図 一。大規模な場合に有効）

b）バスルートを調整して右折してターミナルヘ入る ルートをなくすか（岡山バスターミナル計画では郊外バ ス、都市間バスの全部をターミナルへ入れる事にした）

c）右折して入るべき車は、ターミナルへ人れないか （市内バスはバスストップとする）

d）交差点又はバスターミナル專用のシグナルによつ て出大する。

いまバスターミナルの北端及び南端にシグナルを設埴 し、ターミナル内でのバスの進路を北方一方通行とすれ ばこの点は非常にうまく解決される。

\section{\$4. バスターミナルの規模}

(1) 将来のバス交通量

将来のバス交通量の推定には岡山県の人口 $(1,000$ 人 単位) 及び県民 1,000 人当りバス保有台数、バス 1 台当 り走行距離の 3 つの指標ののび率の積としてバス交通拡 大指数を求めた。

第 2 表

\begin{tabular}{|c|c|c|c|}
\hline & $\begin{array}{c}\text { 成山県人口 } \\
(1,000 \text { 人) }\end{array}$ & $\begin{array}{c}\text { 八ス保有台数 } \\
(1,000 \text { 人当り })\end{array}$ & $\begin{array}{c}\text { 年間ハスス走行距離 } \\
(1,000 \text { キロ })\end{array}$ \\
\hline 1960 & 1,690 & 0.78 & 42 \\
\hline 1970 & 1,690 & 3.70 & 54 \\
\hline のび事 & 1.00 & 4.74 & 1.29 \\
\hline
\end{tabular}

故に、バス交通拡大指数 $=1.00 \times 4.74 \times 1.29=6.11$

ここで将来のバスルートがかなり長距離化する事を考 慮すると実際のバス交通施設に対する負担はこの值より はいく分低いものになる事が予想される。特にバスター ミナルは多くの場合起終点となるのでとのバス施設拡大 指数としては 6 くらいの值をとる事が適当と思われる。 現在岡山市の中心市街地に起終点をもつバスルートで現 在バスターミナルを使用する郊外バス及び都市バスの1 日発着回数は約 500 回と推定されるので、1970年のバス ターミナル終日発着回数はこれとバス施設拡大指数との 
積、すなわち $500 \times 6=3,000$ 回と考えられる。

(2) バース数の算定

現在の日本の多くのバスターミナルといわれているも のでの終白発着台数とバース数との関係を調べてみると ほぼ50：1という值をえた。故に終日発着台数がわかれ ばその $1 / 50$ の值としてバースが求まる事になる。

これは理論的には次のように考えられる。まず乗降客 ラッシュ率 $12 \%$ とするとバスラッシュ率はほほ $10 \%$ と なる。また 1 台のバース待留時間を 12 分とすると 1 時 間に 5 台発着する事になるから $\frac{1}{10} \times \frac{1}{5}=\frac{1}{50}$ となるのであ ろう。

故に、とのバスターミナルでは $3,000 \times \frac{1}{50}=60$ 本のバ 一スが必要である。

(3) バスターミナル所要面積

郊外及び都市間バスのターミナルにおける待留方法は $30^{\circ} 、 45^{\circ} 、 60^{\circ}$ 駐車である。その場合のバース、乗降場及 び付属施設面積をふくめたターミナルの所要面積はバー ス当り約 $200 \mathrm{~m}^{2}$ である。

故に終日発着台数からターミナル所要面積を略算する には $\frac{1}{50} \times 200=4$ 倍すればよい。

さて、岡山バスターミナルの計画敷地は大略 $70 \mathrm{~m} \times$ $190 \mathrm{~m}$ で $13,300 \mathrm{~m}^{2}$ であるから約 3,300 台まで好理が 可能である。

1970 年の推定バス終日発着台数は約 3,000 台である から処理の限界にある事になる。中心市街地の高価な土 地を一尿にしか利用しないという事自体不経済な事であ る。将来は複㐿にして増加する交通に対処すべきであ る。

\section{§5. バスターミナルの施設}

(1) 将来の书公張

目下発展の出発点又は途上にある、都市交通機関とし てのバス輸送を将来にわたつて定量的に推定する事は至 難のわざである。まして、都市間長距離バスとか、20万 の乗降人員を持つバスターミナルという事においては、 いかに手持ちの資料の精密な検討によつても将来大きな 䛊差はまぬがれぬものである。てれに対しては段階的な 焚設と使用方法の諳画によつて対処しなければならない であろう。

すなうち、まず第一に計画敷地地区全体を人手する。 初期においては全教地面積をバスターミナルに使用する 必要はないので一部は駐車場に他は簡易商店緑地その他 に利用する。場合によつては市内バスのターミナ゙ル使用 が許されてもよいと思う。郊外バス、都市閒バスの増加 にともなつて逐次市内バスは追放され、増加にみあつた
バースの增設とターミナル施設の増築がなされていくい きである。との際初期の設計は全体の施設完成時に十分 な考察が払われつつなされるべきである。

(2) ダブルデッキ

ターミナル完成時において、市内バスとの連絡やオフ イス地区への通行は、幹線道路を横断した動線で行われ る。てれをふせぐためにターミナルから㞲東西南北へ数 本の歩行者専用ダブルデッキがかけられるべきである。

将来のこの地区の主な階は 2 階となり、すべて歩行者 専用の通路によつてなされるはずである。てれによつて 通過交通又はサービス交通と人間の動線の明解な分離が なされる。

(3) タクシープール

ターミナルはそれ自体巨大な交通吸引力を持つ施設で あるのでタクシー及び自家用車の集中がはげしくなる。 自家用車ののびは今後 10 年間に 8 倍程度になるととが 予想されるが、们街地中心地区にこれにみあう規模の駐 車施設と道路を作り出す事は財政的にみて不可能なとと であり、また都书交通上からも望ましい事ではない。我 々は都市内部での個人交通はタクシーによるべきである と荐えるし、若干の自家用車用ガレージビルをターミナ ル周辺に建設する事を考慮して、数地队には自家用車の パーキングスペースをおかない事にした。そのかわりタ ーミナルのみならず周辺の阿業地区、業務地区へのサー

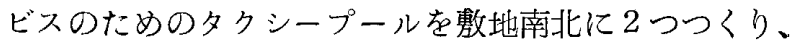
利用者の便に供する事にした。

その所要面積は次のように算定した。バス終日発着回 数が 3,000 回であるからその $40 \%$ つまり 1,200 台の夕 クシーが発着すると考える。との所要面積は $1,200 \mathrm{~m}^{2}$ であり、南北に 2 分しておくと常時約 40 50 台が待期 できるととになる。てれらの車の出入もターミナル出入 のバスと同様、幹線道路に直接面することなく一たん交 差点をまがつてからにする。

\section{結}

都市交通においてバス輸送を主体とした場合、結果的 にはかなりの面積と施設が必要とされる事が判明した が、もしてれをアメリカの諸都市のように自家用車を主 体としたならばとうてい我々にはたえていけないである う。

今後、日本の中小都市での再開発にはバスターミナル の計画が、かなり中心的な位置をしめるのではないかと 思われるか、充分に考虑されたバスター之ナル計画は、 将来の新しい市街地の形態に大きな影響を与えるであろ う。 